\title{
Methotrexate, can we do without it?
}

\author{
Oscar Gonzalez-Llano*, Wendy S. Briones-Ortegon, Julia E. Colunga-Pedraza, and \\ Yahaira V. Jimenez-Antolinez \\ Hematology Service, University Hospital “Dr. José Eleuterio González,"Autonomous University of Nuevo Leon, Monterrey, Nuevo Leon, Mexico
}

Medications such as penicillin, chloramphenicol, and tetracycline emerged during the 1940s. In December 1947, Sydney Farber, a Jewish physician, a pediatric pathologist at the Children's Hospital of Boston administered it, for the $1^{\text {st }}$ time, for the treatment of a child with acute lymphoblastic leukemia (ALL) a new compound, an antifolate agent called aminopterin or methotrexate (MTX), this was provided to Farber by a long-time friend of his Yella Subbaro, a Hindu doctor who was working at the Lederle Laboratories in New York at the time, he had discovered it while he tried to synthesize folic acid, vitamin whose deficiency explained megaloblastic anemia, a very common pathology at that time'.

At varying doses, by different routes of administration, at various stages of each of the diseases and applied alone or in combination with other medications, the following are some of the current indications of MTX: rheumatoid arthritis, psoriasis, atopic dermatitis, Crohn's disease, ectopic pregnancy, head and neck tumors, trophoblastic and choriocarcinoma tumors, breast, lung, and bladder neoplasms, fungoid mycosis, osteosarcoma, Langerhans cell histiocytosis, Hodgkin's lymphoma, various unicellular lymphomas, graft versus host disease, acute myeloblastic leukemia, and $\mathrm{ALL}^{2-4}$.

Next, some aspects of the value of MTX, specifically in the treatment of ALL will be discussed. This is the most common neoplasm in the pediatric age, and it is practically suffered by one in three children with cancer.
Fortunately, it is also one of the neoplasms in which the highest cure rates have been obtained, currently over $75 \%$. Although different chemotherapy protocols are used for their management (total therapy of St. Jude Hospital and the Berlin, Frankfurt, Muenster protocol from the german group, to mention the two most important and used). Most of them divide the treatment of ALL in different phases; induction to remission, consolidation and/or intensification, maintenance of remission, and prophylaxis to prevent infiltration by ALL of the central nervous system (CNS), except for induction, MTX is used in all other phases of treatment ${ }^{5,6}$.

The cases of ALL are divided according to the risk of a relapse to occur in three or four categories, those patients with a high risk of relapse receive more intensive treatment. In our country, as in most of the non-first world countries, most of the cases that are treated belong to this risk group. In part, this can be explained by the delay in their diagnosis. During the intensification phase, high doses of MTX are administered, which ranges between 1 and $5 \mathrm{~g} / \mathrm{m}^{3}$ of body surface, usually in a continuous infusion for $24 \mathrm{~h}$, and generally in four cycles applied every 2 weeks. The value of this treatment scheme has been proven by different groups for many years, although other medications such as cytarabine can be used at high doses, in no way can it replace MTX?

In the prophylaxis phase so that leukemia cells are not present in the CNS, it always includes the administration of intrathecal (IT) chemotherapy of a combination of two

\section{Correspondence:}

*Oscar Gonzalez-Llano

E-mail: droscargonzalezllano@gmail.com
Available online: 09-12-2019

Date of reception: 25-10-2019

Date of acceptance: 29-10-2019 DOI: 10.24875/RMU.19000133
Medicina Universitaria. 2019;21(4):136-137 www.medicinauniversitaria.org

作 (http://creativecommons.org/licenses/by-nc-nd/4.0/). 
or three medications, cytarabine, corticosteroids, and MTX. Of these three drugs mentioned, MTX is the only one that cannot be omitted. The first dose of IT chemotherapy is usually applied in the $1^{\text {st }}$ week after diagnosis, and from there on, it is continued to be administered periodically during the first 12 or 18 months. If despite the prophylactic administration of the IT chemotherapy, the patient develops CNS involvement, the applications of IT chemotherapy are intensified and administered together with the high doses of MTX already mentioned ${ }^{\text {. }}$.

The last phase of the treatment of children with ALL is known as the remission maintenance phase; here, two medications are administered orally, mercaptopurine daily and MTX on a weekly basis, both are started at the end of the intensification phase and continued until the end of treatment, between 24 and 30 months; during this phase, the objective is for the patient to maintain leukocyte counts between 3000 and 4000 per $\mathrm{mm}^{3}$. Although the highest and fastest destruction of leukemic cells occurs at the beginning of treatment, especially in the induction phase, it is the combination of mercaptopurine and MTX as important as the intense initial treatment. There is no way to modify this therapy without having a negative impact on the final result ${ }^{9}$.

Therefore, it can be concluded that at least in the treatment of ALL, the most common cancer in children, MTX cannot be substituted or omitted; not using it would have a very negative effect and would make the cure of a patient very unlikely of a disease that can currently be resolved in more than $70 \%$ of pediatric patients.

\section{Conflicts of interest}

The authors declare that they have no conflicts of interest.

\section{Funding}

No funding was provided for this project.

\section{Ethical disclosures}

Protection of human and animal subjects. The authors declare that no experiments were performed on humans or animals for this study.

Confidentiality of data. The authors declare that no patient data appear in this article.

Right to privacy and informed consent. The authors declare that no patient data appear in this article.

\section{References}

1. Farber S, Diamond LK. Temporary remissions in acute leukemia in children produced by folic acid antagonist, 4-aminopteroyl-glutamic acid. N Engl J Med. 1948;238:787-93.

2. Greb JE, Goldminz AM, Gottlieb AB. Insights on methotrexate in psoriatic disease. Clin Immunol. 2016;172:61-4.

3. Tornero J, Ballina FJ, Calvo J, Ruiz MA, Abello JC, Meseguer AL, et al. Recomendaciones para el uso del metotrexato en artritis reumatoide: incremento y reducción de dosis y vías de administración. Reumatol Clín. 2015;11:3-8.

4. Gomollón F, Rubio S, Charro M, Garcia-Lopez S, Munoz F, Gisbert JP, et al. Recomendaciones del grupo español de trabajo de enfermedad de crohn y colitis ulcerosa (GETECCU) sobre el uso de metotrexato en la enfermedad inflamatoria intestinal. Gastroenterol Hepatol. 2015;38:24-30.

5. Pui $\mathrm{CH}$, Pei D, Raimondi SC, Coustan-Smith $\mathrm{E}$, Jeha S, Cheng $\mathrm{C}$, et al Clinical impact of minimal residual disease in children with different subtypes of acute lymphoblastic leukemia treated with response-adapted therapy. Leukemia. 2017;31:333-9.

6. Schrappe M, Möricke A, Reiter A, Henze G, Welte K, Gadner H, et al. Key treatment questions in childhood acute lymphoblastic leukemia: results in 5 consecutive trials performed by the ALL-BFM study group from 1981 to 2000. Klin Padiatr. 2013;225 Suppl 1:S62-72.

7. Howard SC, McCormick J, Pui CH, Buddington RK, Harvey RD. Preventing and managing toxicities of high-dose methotrexate. Oncologist. 2016; 21:1471-82.

8. Richards S, Pui CH, Gayon P, Childhood Acute Lymphoblastic Leukemia Collaborative Group (CALLCG). Systematic review and meta-analysis of randomized trials of central nervous system directed therapy for childhood acute lymphoblastic leukemia. Pediatr Blood Cancer. 2013:60:185-95

9. Schmiegelow K, Nielsen SN, Frandsen TL, Nersting J. Mercaptopurine/ methotrexate maintenance therapy of childhood acute lymphoblastic leukemia: clinical facts and fiction. J Pediatr Hematol Oncol. 2014;36:503-17. 